Check for updates

Cite this: RSC Adv., 2018, 8, 35485

Received 20th August 2018

Accepted 29th September 2018

DOI: $10.1039 / \mathrm{c} 8 \mathrm{ra06956e}$

rsc.li/rsc-advances

\section{Residue and risk assessment of fluopicolide and cyazofamid in grapes and soil using LC-MS/MS and modified QuEChERS}

\author{
Tianheng Xu, Xiaoxiao Feng, Lixiang Pan, Jing Jing and Hongyan Zhang (D) *
}

\begin{abstract}
The residue behavior of fluopicolide, cyazofamid and their metabolites (M-01, M-02 and CCIM) was evaluated in open field conditions. The dissipation and terminal residue of these five compounds were determined via a modified QuEChERS method, by adjusting the liquid chromatography coupled with tandem mass spectrometry (LC-MS/MS) conditions and optimizing the purification process. This led to a satisfactory average recovery of between $71.6 \%$ and $107.7 \%$, as well as limit of quantitation (LOQ) values of $0.05 \mathrm{mg} \mathrm{kg}^{-1}$. The dissipation results recorded in two places in China illustrated that the halflife values of fluopicolide are 11.4 (Anhui, grape), 19.7 (Anhui, soil) and 21.8 (Hebei, grape), 21.2 (Hebei, soil) days, respectively. As for the dissipation of cyazofamid, it was found to have half-life values of 8.7 (Anhui, grape) and 20.1 (Hebei, grape) days. The final residues in grapes were found to be below the maximum residue limit (MRL) of $2 \mathrm{mg} \mathrm{kg}^{-1}$ for fluopicolide and $1 \mathrm{mg} \mathrm{kg}^{-1}$ for cyazofamid. Thus, a preharvest interval of 10 days and recommended MRLs from the Joint FAO/WHO Meeting on Pesticide Residues (JMPR) are appropriate to ensure the food safety of fluopicolide and cyazofamid in grapes. The hazard quotient $(\mathrm{HQ})$ and acute hazard index $(\mathrm{aHI})$ values were found to be below $100 \%$, demonstrating negligible risk in consuming grapes, regardless of long or short-term exposure.
\end{abstract}

\section{Introduction}

China is the biggest grape producer in the world, producing nearly $20 \%$ of the world's total production. ${ }^{1}$ Differing from the usage of grapes in other countries, which is mainly in the fermenting of wine grapes to wine, the Chinese prefer to consume fresh or dried grapes, accounting for $83 \%$ of the total production. ${ }^{1}$

However, in grape production there is a contradiction between progressive growth in cultivation and protection from different types of plant pathogens, such as grape downy mildew, during the grape growing period. To protect the interests of farmers, fungicides are used during cultivation. ${ }^{2}$ A $25 \%$ suspension agent (SC), mainly composed of fluopicolide (15\%) and cyazofamid (10\%), is to be registered in China for this purpose. Its active ingredients, fluopicolide and cyazofamid, both have advantages in being able to co-function alongside other fungicides without any cross-resistance., ${ }^{3,4}$ This means that they can complement one another in a safe and efficient manner. Fluopicolide, [2,6-dichloro- $N$-[3-chlor5-trifluoromethyl-2-pyridine-methyl]-benzamide], is a systemic fungicide of the novel chemical class of acylpicolide fungicides that targets oomycetes that cause diseases in a wide range of crops. $^{5-7}$ Fluopicolide is registered for use in cabbages, tomatoes, cucumbers, chilies, potatoes, watermelons and onions. ${ }^{8}$ According to biotransformation investigations, 2,6-dichlorobenzamide (M-01

College of Science, China Agricultural University, Beijing, 100193, P. R. China. E-mail: hongyan@cau.edu.cn or BAM) and 3-chloro-5-(trifluoromethyl)pyridine-2-carboxylic acid (M-02) have been confirmed as residues in plants, although M-01 degrades so fast that the Joint FAO/WHO Meeting on Pesticide Residues (JMPR) has not yet established a maximum residue level for it. We considered its detection because it is much more toxic than fluopicolide and other metabolites. ${ }^{7}$ The other ingredient, cyazofamid, [4-chloro-2-cyano- $N, N$-dimethyl-5-(4-methylphenyl)$1 H$-imidazole-1-sulfonamide], is a sulfonamide-based fungicide that was developed by lshihara Sangyo Kaisha Ltd. ${ }^{4}$ It has been widely used to control late blight and downy mildew in agriculture and it has been registered for use in cucumbers, potatoes, grapes and lychees in China. ${ }^{9}$ The detection of 4-chloro-5- $p$-tolylimidazole2-carbonitrile (CCIM), a major urinary metabolite, is required under GB 2763-2016, but not in JMPR. ${ }^{10}$ The structures of the compounds and metabolites are shown in Fig. 1.

Grape processing techniques, such as drying, washing, peeling, fermenting and so on, have proven to be useful in reducing pesticide residues on the surface of the fruit. ${ }^{11}$ As chemicals can be easily absorbed into the edible portion of the fruit and the general public now pay an increasing amount of attention to the toxicity in agricultural products, especially fresh fruit and vegetables, it is vital, meaningful and worth paying more attention to the residues in produce, in this case, fluopicolide and cyazofamid. Hence, more information about pesticide residues has been demanded and thus, it is significant to develop an efficient and effective determination method to monitor fluopicolide, cyazofamid and their metabolites (M-01, M-02 and CCIM) in grapes. 


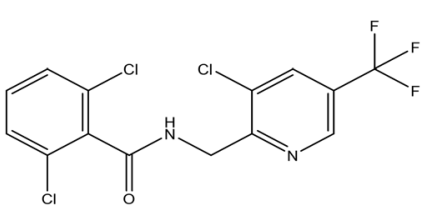

A

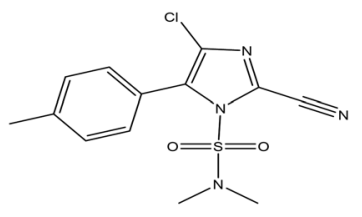

D

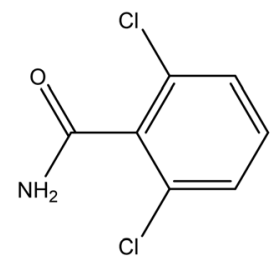

B

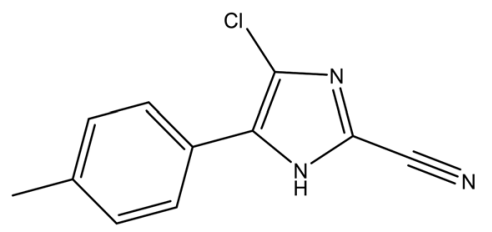

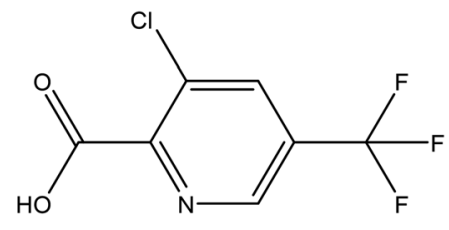

C

Fig. 1 The chemical structures of (A) fluopicolide, (B) M-01, (C) M-02, (D) cyazofamid and (E) CCIM.

Up until now, there have been several reports on the determination of either fluopicolide and its metabolites or cyazofamid and its metabolite. Sample pretreatment methods, such as solid phase extraction (SPE), ${ }^{12-15}$ disperse solid phase extraction (d-SPE) ${ }^{16-18}$ liquid-liquid extraction, ${ }^{19}$ direct injection ${ }^{20}$ and gel permeation chromatography (GPC) ${ }^{19}$ have been reported. So, it is feasible to detect both the parent material and metabolites in different matrices. However, there have been a few studies that have reported the simultaneous determination of fluopicolide, cyazofamid and their metabolites (M-01, M-02, and CCIM). In addition, the reported pretreatments are too time-consuming, ${ }^{19}$ complicated and expensive because of the need for a large volume of solvent ${ }^{13}$ and clean-up materials, such as Florisil. ${ }^{14,15}$

The QuEChERS method was first reported in 2003. ${ }^{21}$ The original study demonstrated that the process requires the use of less solvent and has better pretreatment efficiency in extracting pesticide residues in vegetables and fruits. Nowadays, the QuEChERS method is a basis for method development in laboratories, via the use of other cleaning agents, other solvents, and the replacing of GC/MS with LC/MS and HPLC.

The aim of this study was to develop a method based on the QuEChERS method for analyzing fluopicolide, cyazofamid and their metabolites (M-01, M-02 and CCIM) in grapes and soil. Meanwhile, the dissipation dynamics and terminal residues of fluopicolide, cyazofamid and their metabolites (M-01, M-02 and CCIM) in grape and soil samples from Hebei and Anhui province, China, were investigated.

\section{Experimental}

\subsection{Materials and methods}

2.1.1. Reagents. Fluopicolide ( $95 \%$ purity), cyazofamid (98.7\% purity) and metabolite CCIM (99.48\%) were purchased from BeNa Culture Collection, China. Dr Ehrenstorfer GmbH supplied one of the analytical standard fluopicolide metabolites M-01 (99\% purity), while Ferrochem Ltd supplied M-02 (97\% purity). HPLC grade acetonitrile was purchased from Fisher Scientific (Pittsburgh, PA, USA) and ultrapure water was purchased from Aquapro Ultrapure Water System (Aquapro International Company LLC, Chongqing, China). Sinopharm Chemical Reagent Co. Ltd., Shanghai, China, supplied formic acid (98\% purity). Anhydrous magnesium sulfate $\left(\mathrm{MgSO}_{4}\right)$ and sodium chloride $(\mathrm{NaCl})$ purchased from Beijing Reagent Company (Beijing, China) were baked at $110{ }^{\circ} \mathrm{C}$ for $8 \mathrm{~h}$ before use. The Agela Cleanert $\mathrm{C}_{18}$ sorbent (40$60 \mu \mathrm{m})$ was purchased from Agela Technologies, Tianjin, China. Aqueous solutions of formic acid were prepared prior to every sample extraction and chromatographic separation.

2.1.2. Apparatus. A TARGIN VX-III Multi-Tube Vortexer was used to eddy the CORNING centrifuge tubes in the sample preparation process, purchased from Haimen Kylin-Bell Lab Instruments Co., Ltd. Centrifugation for all of the sample preparation was completed using an RJ-TDL-40B low-speed desktop centrifuge $(8 \times 50 \mathrm{~mL})$ purchased from Jiangsu Ruijiang Co., Ltd., China, and a TG16MW micro-centrifuge $(24 \times$ $2.0 \mathrm{~mL}$ ) from Hunanherexi Instrument \& Equipment Co., Ltd., China.

2.1.3. Standard solution preparation. The individual standard solutions (about $1000 \mathrm{mg} \mathrm{L}^{-1}$ ) of the five chemicals were prepared with acetonitrile by weighing $24.0 \mathrm{mg}$ of fluopicolide, $22.2 \mathrm{mg}$ of M-01 and $23.5 \mathrm{mg}$ of M-02 and making the volume up to $25 \mathrm{~mL}$ with HPLC grade acetonitrile, while $9.2 \mathrm{mg}$ of cyazofamid and $8.9 \mathrm{mg}$ of CCIM were separately made up to volumes of $10 \mathrm{~mL}$. The solutions were stored in a fridge at $-20{ }^{\circ} \mathrm{C}$. Standard solutions for spiking and calibration were prepared by diluting individual standard solutions with acetonitrile. As for the calibration solutions, matrixmatched calibration solutions were prepared by diluting the standard solutions with blank soil and grape extracts. 


\subsection{HPLC-MS/MS analytical conditions}

An Agilent 1200 HPLC system equipped with a reversed-phase column (Athena C18-WP analytical column, $50 \mathrm{~mm} \times 2.1 \mathrm{~mm}$ i.d., $3.0 \mu \mathrm{m}$ particle size) was used to achieve the separation of fluopicolide, cyazofamid and their metabolites at $30{ }^{\circ} \mathrm{C}$. The binary mobile phase was composed of HPLC grade methanol and $0.1 \%$ formic acid water $(65: 35, \mathrm{v} / \mathrm{v})$, in isocratic elution mode. The flow rate and injection volume were set to 0.3 $\mathrm{mL} \min ^{-1}$ and $5 \mu \mathrm{L}$.

As for the MS/MS conditions, a triple-quadrupole mass spectrometer (6410 Triple Quad) equipped with an ESI source, was used to analyze fluopicolide, cyazofamid and their metabolites in positive ionization mode. The gas flow $\left(\mathrm{N}_{2}\right)$ rate was set to 8.00 $\mathrm{L} \min ^{-1}$ with a temperature of $350{ }^{\circ} \mathrm{C}$. The capillary voltage used was $4 \mathrm{kV}$, and the pressure of the nebulizer was 35 psi. According to the results recorded in full scan mode, two high response product ions were set for each compound, for qualification and quantitation with optimized fragmentor (V) and collision energy values (V), respectively. The detailed MS/MS parameters of the five target compounds are listed in Table 1.

\subsection{Field trials}

Field experiments were carried out according to NY/T 788-2004 ${ }^{22}$ over one year in two places, Hebei Longyao and Anhui Suzhou. Each experiment consisted of a control and six treatments reflecting the final residues for the different dosage and dissipation results at the recommended dosage.

The terminal residue trial was implemented with the recommended dosage of $62.5 \mathrm{mg} \mathrm{kg}^{-1}$ and a higher dosage of $93.75 \mathrm{mg}$ $\mathrm{kg}^{-1}$ (1.5 times the recommended dosage). A $25 \%$ SC formulation, in which the active ingredients were $15 \%$ fluopicolide and $10 \%$ cyazofamid, was applied three or four times. Moreover, an interval of seven days was set both at the low or high level. Each treatment had three replicate plots. Representative grape and soil samples were randomly gathered at pre-harvest intervals (PHI) of 7, 10 and 14 days in each plot after last spraying.

The dissipation residue experiment in the supervised trial began at a time where the grape was halfway through its maturity, with a value of $93.75 \mathrm{mg} \mathrm{kg}^{-1}$ (1.5 times the recommended dosage). Each treatment group had three replicate plots. Representative grape and soil samples were randomly collected at intervals of $0,1,3,5,7,14,21$ and 30 days in each plot after last spraying.

Blank control plots were also set as a contrast. All of the samples were stored at $-20{ }^{\circ} \mathrm{C}$ for the following analysis.

\subsection{Sample preparation}

$10 \mathrm{~g}$ of thoroughly homogenized grape or soil sample was accurately weighed into a $50 \mathrm{~mL}$ centrifuge tube. The QuEChERS method initially developed for vegetables and fruits involved the use of plenty of water, so in this study, a modified preparation method was followed where water was added to the soil or sugarladen grape samples to dissolve them into acetonitrile to result in less of a matrix effect. The grape samples were processed with $5 \mathrm{~mL}$ of a $2 \%$ aqueous solution of formic acid and $10 \mathrm{~mL}$ of acetonitrile for extraction, while for the soil samples, $10 \mathrm{~mL}$ of a $2.5 \%$ aqueous solution of formic acid and $10 \mathrm{~mL}$ of a $2.5 \%$ aqueous solution of formic acid and acetonitrile were used. After adding $6 \mathrm{~g}$ of anhydrous sodium chloride to ensure separation between the organic and aqueous phase, the centrifuge tubes were eddied for $5 \mathrm{~min}$ using a multi-tube vortexer to ensure full interaction between the extraction solvent and sample. The samples were centrifuged for $5 \mathrm{~min}$ at $3800 \mathrm{rpm}$.

In the clean-up process, $1 \mathrm{~mL}$ of supernatant was extracted according to described procedure and was purified using $200 \mathrm{mg}$ of anhydrous magnesium sulfate for the grape samples and $100 \mathrm{mg}$ of anhydrous magnesium for the soil samples. The mixtures were whirled drastically by the vortexer for $30 \mathrm{~s}$. Then, the acetonitrile layer was filtered through a $0.22 \mu \mathrm{m}$ filter into a vial for LC-MS/MS analysis.

\subsection{Statistical analysis}

The matrix effect is identified as a signal suppression or enhancement, and it is a major drawback in quantitative analysis carried out by liquid chromatography-mass spectrometry (LCMS). Considering its impact on the method parameters, formula (1) below can be used to calculate the extent of the effect:

$$
\operatorname{ME}(\%)=(\text { slope matrix/slope solvent }) \times 100 \%
$$

Obviously, a value above $100 \%$ represents ionization enhancement, while a value below $100 \%$ indicates ionization suppression. $^{23}$

The residue levels of fluopicolide and cyazofamid in the grape and soil samples fits the one-exponential kinetics eqn (2):

$$
C=C_{0} \mathrm{e}^{-k t}
$$

and the half-life of the pesticide could be calculated using eqn (3):

$$
T_{1 / 2}=(\ln 2) / k
$$

\begin{tabular}{|c|c|c|c|c|c|c|c|}
\hline \multirow{2}{*}{$\frac{\text { No. }}{1}$} & \multirow{2}{*}{$\begin{array}{l}\text { Compound } \\
\text { Fluopicolide }\end{array}$} & \multirow{2}{*}{$\frac{t_{\mathrm{R}}(\mathrm{min})}{2.37}$} & \multicolumn{2}{|c|}{$\begin{array}{l}\text { Ion transition } \\
\text { (*represents quantification) }\end{array}$} & \multirow{2}{*}{$\frac{\text { Fragmentor }(\mathrm{V})}{110}$} & \multirow{2}{*}{$\begin{array}{l}\text { Collision energy (V) } \\
19,55\end{array}$} & \multirow{2}{*}{$\frac{\operatorname{MRM}(+/-)}{+}$} \\
\hline & & & 384.3 & $172.6 *, 145.8$ & & & \\
\hline 2 & Cyazofamid & 3.60 & 325.1 & $108.1 *, 216.1$ & 70 & 10,10 & + \\
\hline 3 & M-01 & 0.69 & 190.0 & $172.8^{*}, 144.9$ & 105 & 15,30 & + \\
\hline 4 & M-02 & 1.11 & 226.0 & $180.0 *, 208.1$ & 60 & 20,5 & + \\
\hline 5 & CCIM & 2.90 & 218.1 & $139.0 *, 130.1,182.1$ & 120 & $25,40,30$ & + \\
\hline
\end{tabular}

Table 1 The HPLC-MS/MS parameters of fluopicolide, cyazofamid, M-01, M-02 and CCIM 


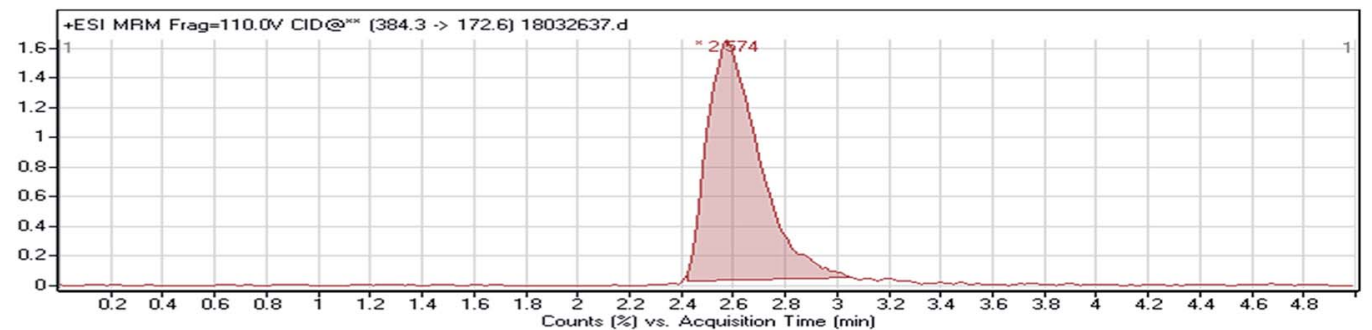

(A) fluopicolide

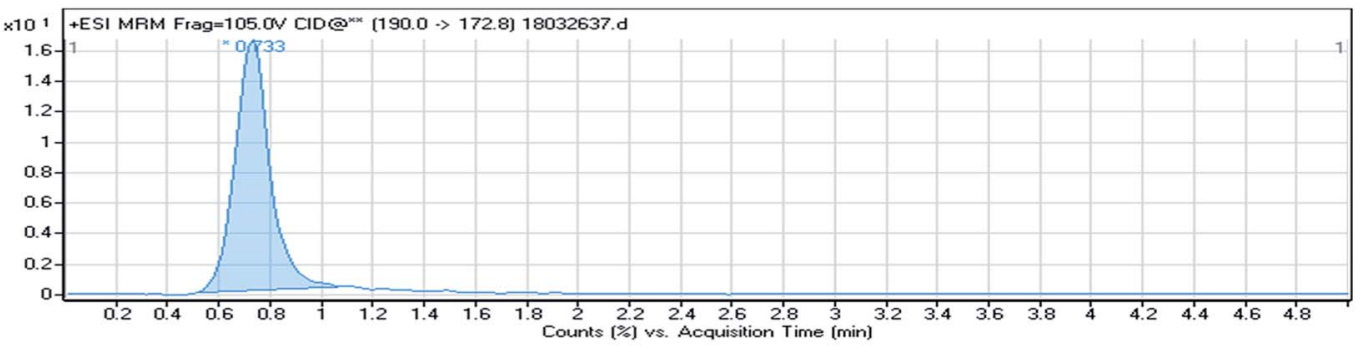

(B) $\mathrm{M}-01$

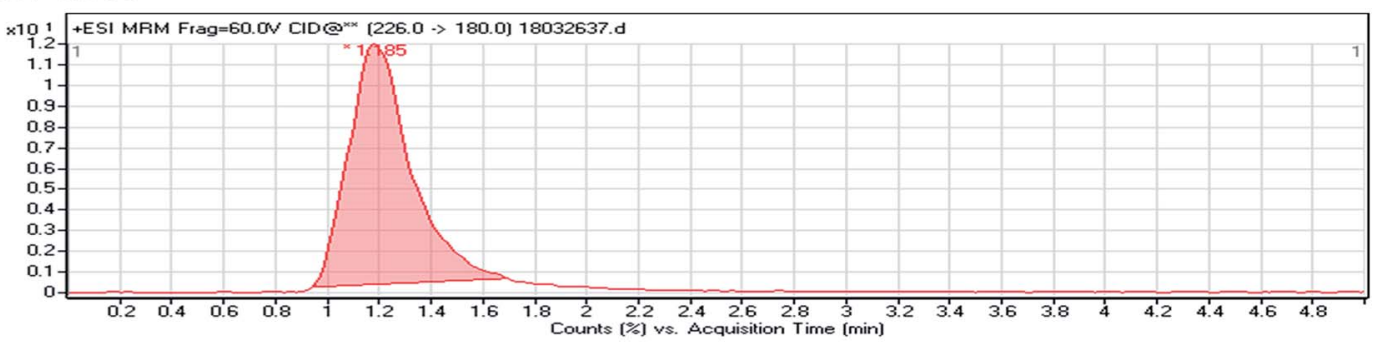

(C) $\mathrm{M}-02$

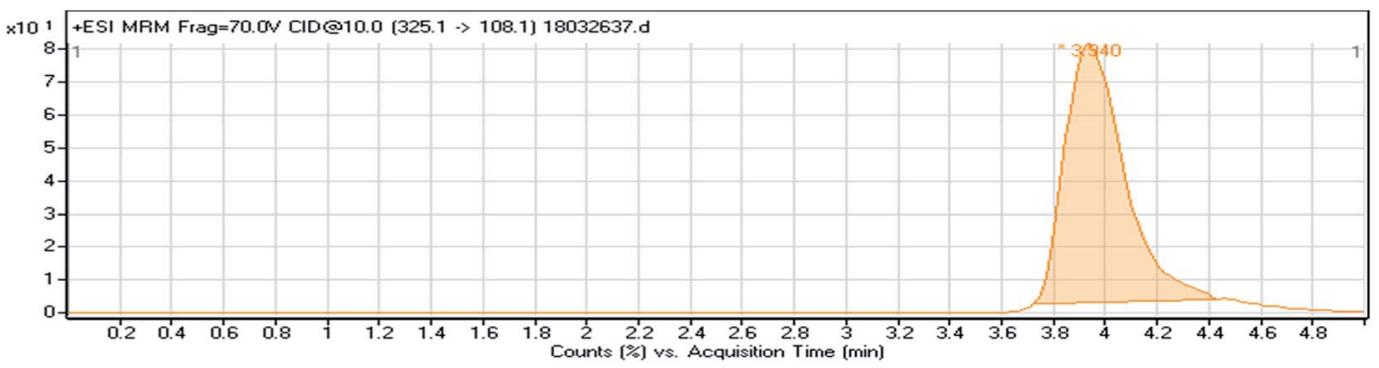

(D) cyazofamid

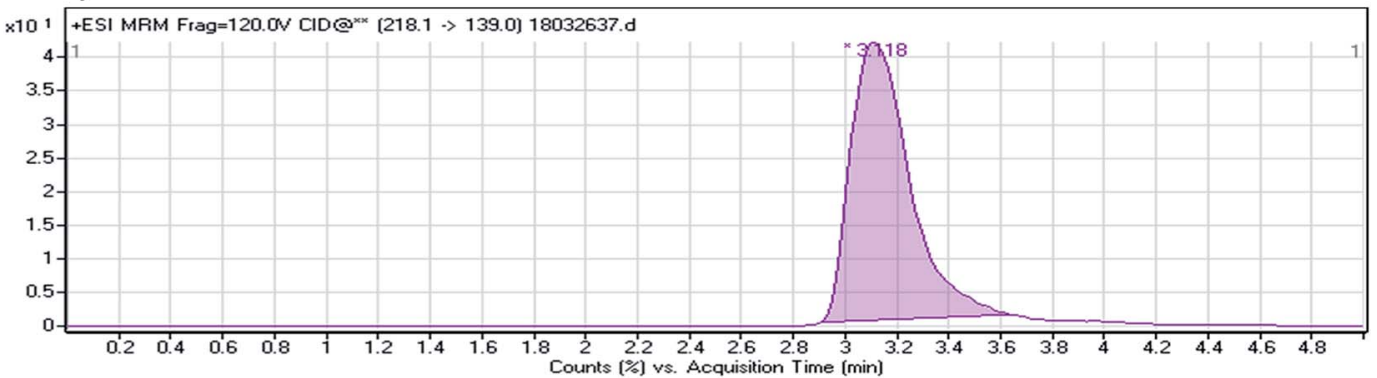

(E) CCIM

Fig. 2 Typical HPLC-MS/MS chromatograms of fluopicolide, M-01, M-02, cyazofamid and CCIM in acetonitrile (concentration of 1 mg $L^{-1}$ ).

where $t$ represents the time $(d)$ since the pesticide was supplemented, $C$ represents the concentration $\left(\mathrm{mg} \mathrm{kg}^{-1}\right)$ of the pesticide residue at a time, $t, C_{0}$ represents the initial residue concentration $\left(\mathrm{mg} \mathrm{kg}^{-1}\right), k$ is the degradation rate. $T_{1 / 2}$ represents the time taken for the pesticide residue level to fall to half of the initial residue level after application. The data were processed using the Systat Sigmaplot v12.5 software.

Assessment of the dietary exposure and long-term risk of grape consumption were made using the eqn (4) and (5): ${ }^{24}$

$$
\mathrm{EDI}=\mathrm{STMR} \times \mathrm{Fi} / \mathrm{bw}
$$




$$
\mathrm{HQ}=\mathrm{EDI} / \mathrm{ADI} \times 100 \%
$$

where EDI is the estimated daily intake $\left(\mathrm{mg} \mathrm{kg}^{-1}\right.$ per bw per day). STMR represents the median residue level $\left(\mathrm{mg} \mathrm{kg}^{-1}\right)$. Fi is the grape intake weight per day $\left(\mathrm{kg} \mathrm{day}^{-1}\right)$. bw is the average weight of an adult ( $\mathrm{kg}$, which is $60 \mathrm{~kg}$ here $^{25}$ ), ADI is the acceptable daily intake ( $\mathrm{mg} \mathrm{kg}^{-1}$ per day per bw) and $\mathrm{HQ}$ is the hazard quotient. A HQ value of over $100 \%$ indicates an unacceptable level of risk, while a value below $100 \%$ indicates an acceptable level of risk.

In addition, the short-term risk assessment was evaluated using the following eqn (6) ${ }^{26}$ and (7): $:^{27}$

$$
\begin{aligned}
& \text { IESTI }=[\mathrm{LP} \times \mathrm{HR} \times v] / \mathrm{bw} \\
& \mathrm{aHI}=\mathrm{ESTI} / \mathrm{ARfD} \times 100 \%
\end{aligned}
$$

where ESTI is the estimated short-term daily intake $\left(\mathrm{mg} \mathrm{kg}^{-1}\right.$ per bw per day), $U$ represents the unit weight of the edible portion of the grape (0.6366 kg here) ${ }^{26} \mathrm{HR}$ is the calculated highest residue level $\left(\mathrm{mg} \mathrm{kg}^{-1}\right), v$ is the coefficient of variation for the grape (which is 3 here $^{27}$ ), and LP represents the largest portion of food provided per day $(0.3667 \mathrm{~kg}$ here $) .{ }^{26}$ When $U$ is higher than LP, eqn (6) is used to calculate the international estimated short-term intake (IESTI). ARfD is the acute reference dose $\left(\mathrm{mg} \mathrm{kg}^{-1}\right.$ per bw). An acute hazard index (aHI) with a value above $100 \%$ indicates an unacceptable level of risk, while a value below $100 \%$ indicates an acceptable level of risk.

\section{Result and discussion}

\subsection{Optimization of the method}

3.1.1. Optimization of the HPLC-MS/MS conditions. As the mobile phase composition plays an important role in the retention time, response and peak shape of the HPLC separation, ${ }^{28}$ mobile phases of acetonitrile-water (water containing $0.1 \%$ formic acid) and methanol-water (water containing $0.1 \%$ formic acid) were tested. Higher responses and sharper peaks were obtained when a methanol-water mobile phase was used. According to the data recorded from the testing of different methanol compositions $(90 \%, 85 \%, 80 \%, 75 \%, 70 \%, 65 \%$, and $60 \%)$ and different flow velocities $(0.35,0.3$, and 0.25 $\mathrm{mL} \mathrm{min}^{-1}$ ), a methanol composition of $65 \%$ and velocity of 0.3 $\mathrm{mL} \min ^{-1}$ gave a better performance in terms of a high response, well-shaped peaks and appropriate retention time. Representative HPLC-MS/MS chromatograms of fluopicolide, M-01, M-02, cyazofamid and CCIM are shown in Fig. 2 .

3.1.2. Optimization of the grape pre-treatment. Because the grape samples have potential interferences, different

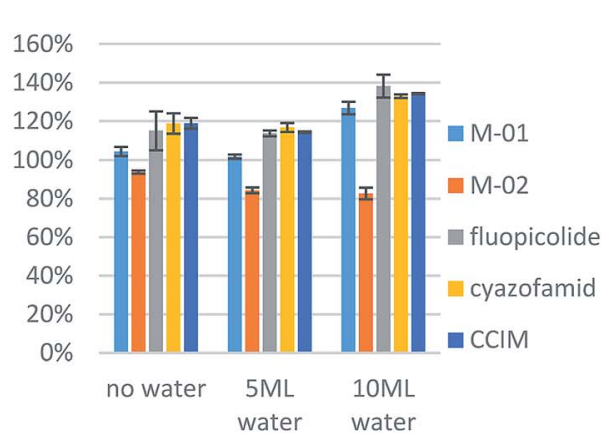

(A)

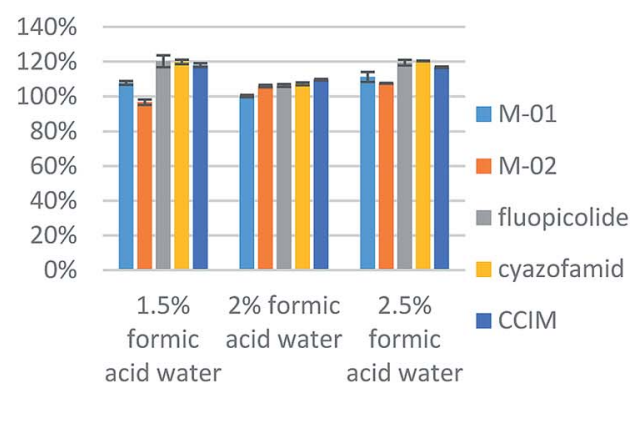

(B)

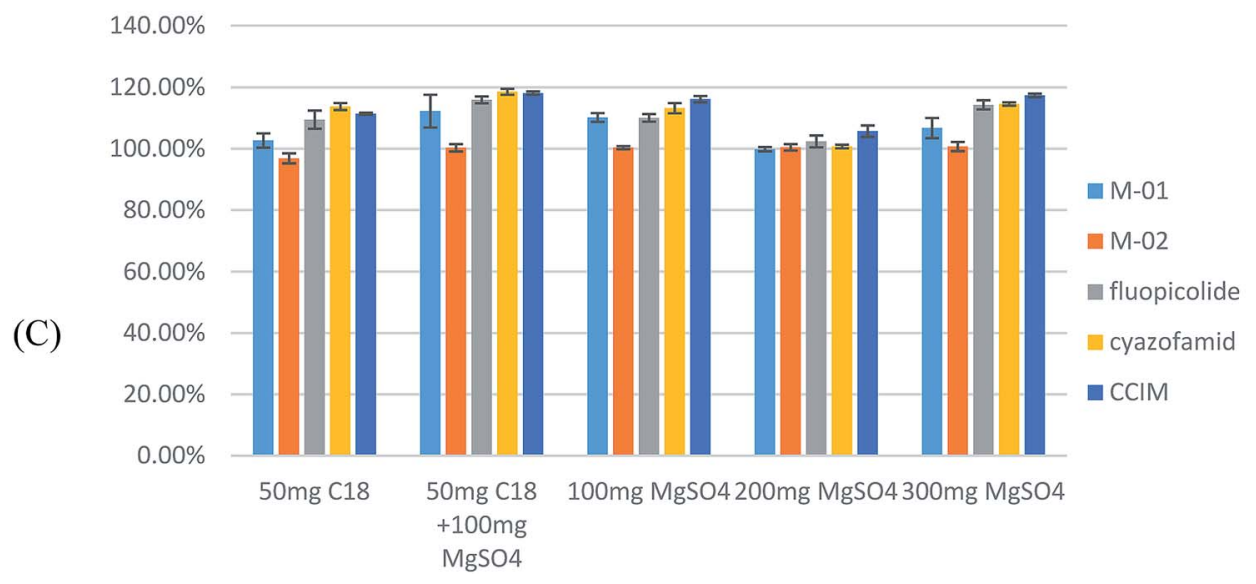

Fig. 3 (A) Recoveries ( $n=3$ ) of fluopicolide, M-01, M-02, cyazofamid and CCIM at $1 \mathrm{mg} \mathrm{kg}^{-1}$ with various volumes of water ( $0 \mathrm{~mL}, 5 \mathrm{~mL}$ and $10 \mathrm{~mL}$ ). (B) Recoveries $(n=3)$ of fluopicolide, M-01, M-02, cyazofamid and CCIM at $1 \mathrm{mg} \mathrm{kg}^{-1}$ with various concentrations of aqueous solutions of formic acid $\left(1.5 \%, 2 \%\right.$ and $2.5 \%$ ). (C) Recoveries $(n=3)$ of fluopicolide, $M-01, M-02$, cyazofamid and CCIM at $1 \mathrm{mg} \mathrm{kg}^{-1}$ purified from a grape matrix using different compositions of sorbents ( $100 \mathrm{mg}$ of $\mathrm{MgSO}_{4}, 200 \mathrm{mg}$ of $\mathrm{MgSO}_{4}, 300 \mathrm{mg}$ of $\mathrm{MgSO}_{4}, 100 \mathrm{mg}$ of $\mathrm{MgSO}_{4}$ with $50 \mathrm{mg}$ of $\mathrm{C}_{18}$, and 50 mg of $\mathrm{C}_{18}$ ). 
solvent and sorbents were tested to achieve the best extraction and purification effects. ${ }^{23}$ According to our previous literature searches and considering molecule structure analysis, M-02 is an acidic compound. Due to this, PSA was not considered when choosing a sorbent.

To investigate the extraction efficiency, studies were carried out on pesticide recoveries using grape samples spiked with target pesticides at $1 \mathrm{mg} \mathrm{kg}{ }^{-1}(n=3)$. Spiked samples were extracted using different volumes of acetonitrile, water and formic acid. $10 \mathrm{~mL}$ of acetonitrile containing different volumes of water $(0,5$, and $10 \mathrm{~mL})$ was tested. As can be seen in Fig. 3A, compared to the samples containing no added water, the addition of $5 \mathrm{~mL}$ of water leads to a lower deviation and higher response for cyazofamid. With respect to adding $10 \mathrm{~mL}$ of water, this process results in a recovery of above $120 \%$. On the basis of adding $5 \mathrm{~mL}$ of water, different concentrations of formic acid in water were tested. A $2 \%$ aqueous solution of formic acid was selected for further study. The results are illustrated in Fig. 3B.

With respect to the cleanup efficiency, the grape samples were spiked with the target pesticides at $1 \mathrm{mg} \mathrm{kg}^{-1}(n=3)$ to study the pesticide recoveries. Then a diverse range of sorbent compositions (100 mg of $\mathrm{MgSO}_{4}, 100 \mathrm{mg}$ of $\mathrm{MgSO}_{4}$ with $50 \mathrm{mg}$ of $\mathrm{C}_{18}$, and $50 \mathrm{mg}$ of $\mathrm{C}_{18}$ ) were tested. The addition of $\mathrm{C}_{18}$ was observed to make no difference compared with the results from adding only $100 \mathrm{mg}$ of $\mathrm{MgSO}_{4}$. Taking efficiency and economy into consideration, it is more reasonable to choose $\mathrm{MgSO}_{4}$ as a sorbent, so $100 \mathrm{mg}$ of $\mathrm{MgSO}_{4}, 200 \mathrm{mg}$ of $\mathrm{MgSO}_{4}$ and $300 \mathrm{mg}$ of $\mathrm{MgSO}_{4}$ were tested. The use of $200 \mathrm{mg}$ of $\mathrm{MgSO}_{4}$ resulted in sharper peaks, and better recovery and precision. The results are shown in Fig. 3C.

3.1.3. Optimization of the soil pre-treatment. Water was found to be necessary for the extraction of the residues in soil samples. The same as the optimization of the grape samples, we altered the concentrations of formic acid in both water and acetonitrile, and also the amount of $\mathrm{MgSO}_{4}$ used. Finally, 2.5\% formic acid in both water and acetonitrile and $100 \mathrm{mg}$ of $\mathrm{MgSO}_{4}$ were selected as the conditions. The results are shown in Fig. 4.

3.1.4. Method validation. Matrix-matched calibration curves were drawn by taking the peak area as the $y$-axis and plotting it against the compound concentrations $(x)$ for seven different groups of data. The data were found to have a good linear fit, with a value of $R^{2}>0.99(n=3)$.

The limit of detection (LOD), producing a signal-to-noise ratio of three, was calculated by the lowest concentration. The lowest spiked concentration level of the compounds was set as the limit of quantification (LOQ). ${ }^{29}$ The corresponding LODs in grape and soil samples that fit the legal recommendations are listed in Table 2. MEs were also calculated and are presented in the table, and it can be seen that the grape samples have lower MEs, both in ionization suppression or enhancement, after processing.

In order to test and confirm the accuracy and precision of the method, recovery experiments of the five compounds in two matrices were processed at four spiking concentration levels with five replicates. The results are shown in Table 2 , and reflect the precision and accuracy of the method. ${ }^{30}$ Representative
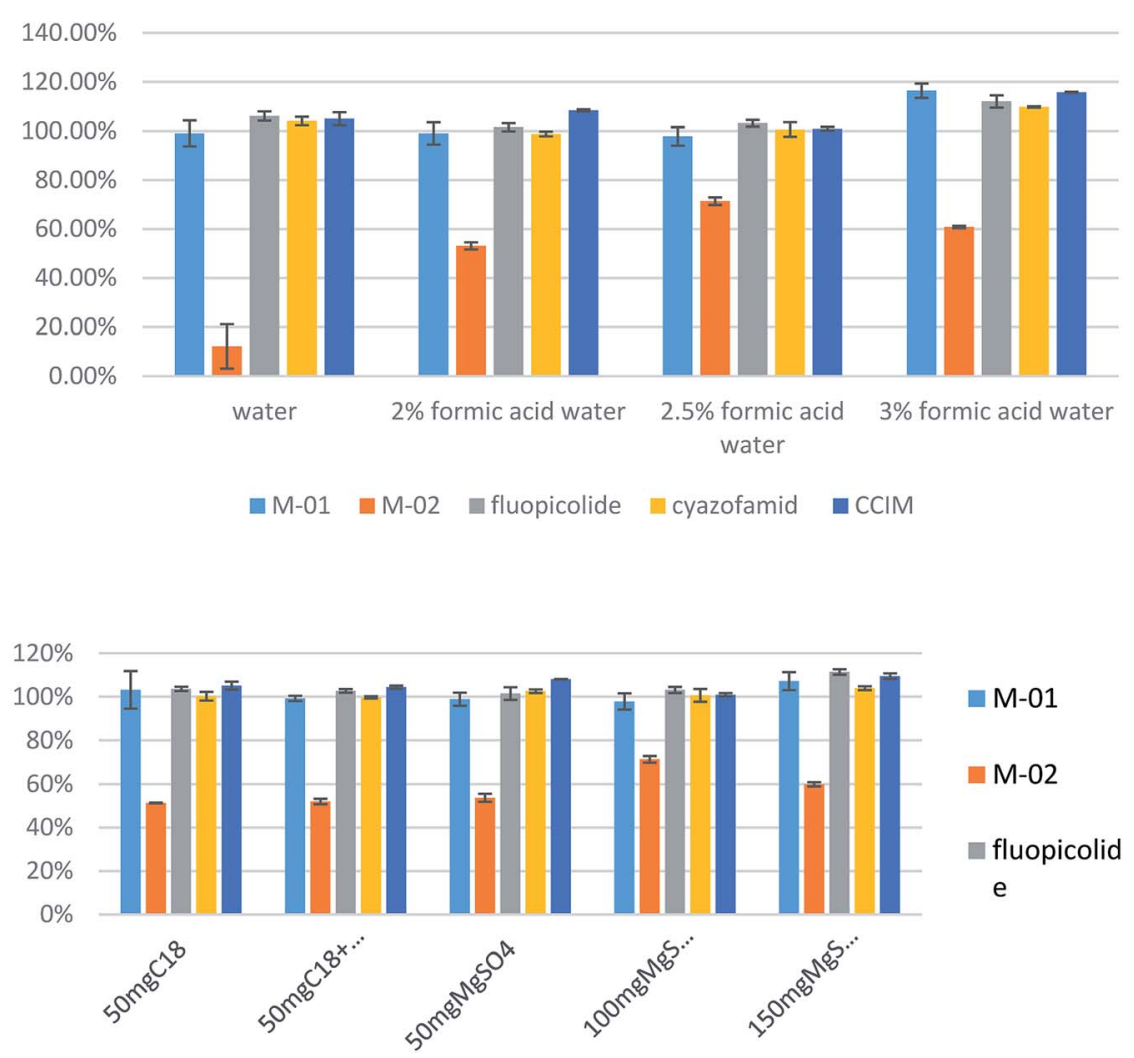

Fig. 4 (A) Recoveries $(n=3)$ of fluopicolide, M-01, M-02, cyazofamid and CCIM at $1 \mathrm{mg} \mathrm{kg}^{-1}$ with various concentrations of aqueous solutions of formic acid $\left(0 \%, 2 \%, 2.5 \%\right.$, and $3 \%$ ). (B) Recoveries $(n=3)$ of fluopicolide, M-01, M-02, cyazofamid and CCIM at $1 \mathrm{mg} \mathrm{kg}^{-1}$, purified using different sorbent compositions (100 mg of $\mathrm{MgSO}_{4}, 200 \mathrm{mg}$ of $\mathrm{MgSO}_{4}, 300 \mathrm{mg}$ of $\mathrm{MgSO}_{4}, 100 \mathrm{mg}$ of $\mathrm{MgSO}_{4}$ with $50 \mathrm{mg}$ of $\mathrm{C}_{18}$, and $50 \mathrm{mg}$ of $\mathrm{C}_{18}$ ). 
HPLC-MS/MS graphs of fluopicolide, cyazofamid and their metabolites (M-01, M-02, CCIM) in matrix standards are shown in Fig. 2.

\subsection{Data analysis}

3.2.1. Terminal residue of fluopicolide and cyazofamid in grape and soil samples. Pesticide residues in samples (grape and soil) from supervised fields in Hebei Longyao and Anhui Suzhou were analyzed using the developed method. The terminal residue results are listed in Table 3 and 4 . The residue results of M-01, M-02 and CCIM were found to be below the LOQs. No matter what dosage conditions and internal samples were are sprayed in, the fluopicolide and cyazofamid residues in soil and grapes from these two provinces were found to be lower than the MRLs (2 $\mathrm{mg} \mathrm{kg}^{-1}$ for fluopicolide and $1 \mathrm{mg} \mathrm{kg}^{-1}$ for cyazofamid).

Table 2 Average recoveries $(\%, n=5)$, calibration curves $(n=3)$, determination coefficients $\left(R^{2}\right)$, LODs and matrix effects (ME) for fluopicolide, M-01, M-02, cyazofamid and CCIM in grape and soil samples

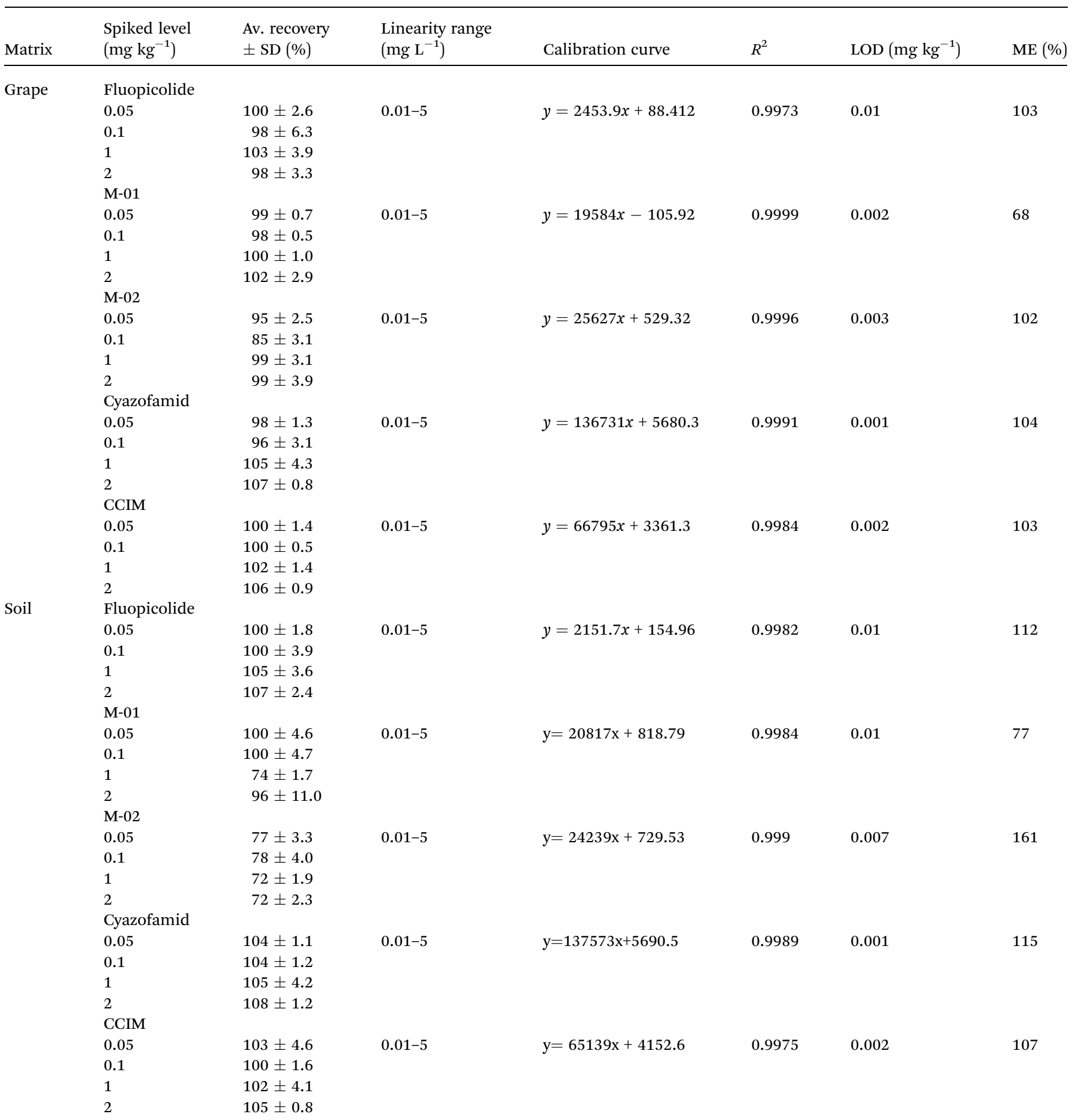


Table 3 Terminal residues of fluopicolide, cyazofamid and their metabolites in grapes in supervised field trials (2017) in (A) Hebei and (B) Anhui

\begin{tabular}{|c|c|c|c|c|c|c|c|c|}
\hline \multirow[b]{2}{*}{ Sample } & \multirow[b]{2}{*}{ Dosage $\left(\mathrm{mg} \mathrm{kg}^{-1}\right)$} & \multirow[b]{2}{*}{ Spray times } & \multirow[b]{2}{*}{ PHI (day) } & \multicolumn{5}{|c|}{ Residue $\left(\mathrm{mg} \mathrm{kg}^{-1}\right)$} \\
\hline & & & & Fluopicolide & M-01 & M-02 & Cyazofamid & CCIM \\
\hline & & & 10 & 0.20 & $<0.05$ & $<0.05$ & 0.15 & $<0.05$ \\
\hline & & & 14 & 0.13 & $<0.05$ & $<0.05$ & 0.083 & $<0.05$ \\
\hline & & 4 & 7 & 0.26 & $<0.05$ & $<0.05$ & 0.18 & $<0.05$ \\
\hline & 93.75 & 3 & 7 & 0.17 & $<0.05$ & $<0.05$ & 0.12 & $<0.05$ \\
\hline & & & 10 & 0.47 & $<0.05$ & $<0.05$ & 0.40 & $<0.05$ \\
\hline & & & 14 & 0.19 & $<0.05$ & $<0.05$ & 0.15 & $<0.05$ \\
\hline & & 4 & 7 & 0.19 & $<0.05$ & $<0.05$ & 0.15 & $<0.05$ \\
\hline & & & 10 & 0.69 & $<0.05$ & $<0.05$ & 0.52 & $<0.05$ \\
\hline & & & 14 & 0.29 & $<0.05$ & $<0.05$ & 0.22 & $<0.05$ \\
\hline & & & 10 & 0.21 & $<0.05$ & $<0.05$ & 0.096 & $<0.05$ \\
\hline & & & 14 & 0.18 & $<0.05$ & $<0.05$ & 0.13 & $<0.05$ \\
\hline & 93.75 & 3 & 7 & 0.21 & $<0.05$ & $<0.05$ & 0.14 & $<0.05$ \\
\hline & & & 10 & 0.24 & $<0.05$ & $<0.05$ & 0.20 & $<0.05$ \\
\hline & & & 14 & 0.18 & $<0.05$ & $<0.05$ & 0.18 & $<0.05$ \\
\hline & & 4 & 7 & 0.21 & $<0.05$ & $<0.05$ & 0.12 & $<0.05$ \\
\hline & & & 10 & 0.35 & $<0.05$ & $<0.05$ & 0.24 & $<0.05$ \\
\hline & & & 14 & 0.37 & $<0.05$ & $<0.05$ & 0.19 & $<0.05$ \\
\hline
\end{tabular}

After valuing the results of the terminal residues and referencing the MRLs established by JMPR, ${ }^{7,10}$ a dosage of $62.5-$ $93.75 \mathrm{mg} \mathrm{kg}^{-1}$ and a harvest interval of 10 days was found to be suitable for a combined $25 \%$ SC formulation of fluopicolide and cyazofamid to be applied on grapes.

3.2.2. Dissipation of fluopicolide and cyazofamid in grape and soil samples. Details of the dissipation residue results are

Table 4 Terminal residues of fluopicolide, cyazofamid and their metabolites in soil in supervised field trials (2017) in (A) Hebei and (B) Anhui

\begin{tabular}{|c|c|c|c|c|c|c|c|c|}
\hline \multirow[b]{2}{*}{ Sample } & \multirow[b]{2}{*}{ Dosage $\left(\mathrm{mg} \mathrm{kg}^{-1}\right)$} & \multirow[b]{2}{*}{ Spray times } & \multirow[b]{2}{*}{ PHI (day) } & \multicolumn{5}{|c|}{ Residue $\left(\mathrm{mg} \mathrm{kg}^{-1}\right)$} \\
\hline & & & & Fluopicolide & M-01 & M-02 & Cyazofamid & CCIM \\
\hline \multirow[t]{12}{*}{ Soil (A) } & \multirow[t]{6}{*}{62.5} & \multirow[t]{3}{*}{3} & 7 & 0.079 & $<0.05$ & $<0.05$ & $<0.05$ & $<0.05$ \\
\hline & & & 10 & 0.079 & $<0.05$ & $<0.05$ & $<0.05$ & $<0.05$ \\
\hline & & & 14 & 0.26 & $<0.05$ & $<0.05$ & 0.064 & $<0.05$ \\
\hline & & \multirow[t]{3}{*}{4} & 7 & $<0.05$ & $<0.05$ & $<0.05$ & $<0.05$ & $<0.05$ \\
\hline & & & 10 & 0.10 & $<0.05$ & $<0.05$ & $<0.05$ & $<0.05$ \\
\hline & & & 14 & $<0.05$ & $<0.05$ & $<0.05$ & $<0.05$ & $<0.05$ \\
\hline & \multirow[t]{6}{*}{93.75} & \multirow[t]{3}{*}{3} & 7 & 0.15 & $<0.05$ & $<0.05$ & 0.063 & $<0.05$ \\
\hline & & & 10 & 0.37 & $<0.05$ & $<0.05$ & 0.125 & $<0.05$ \\
\hline & & & 14 & 0.069 & $<0.05$ & $<0.05$ & $<0.05$ & $<0.05$ \\
\hline & & \multirow[t]{3}{*}{4} & 7 & 0.28 & $<0.05$ & $<0.05$ & 0.092 & $<0.05$ \\
\hline & & & 10 & 0.32 & $<0.05$ & $<0.05$ & 0.092 & $<0.05$ \\
\hline & & & 14 & 0.22 & $<0.05$ & $<0.05$ & 0.066 & $<0.05$ \\
\hline \multirow[t]{12}{*}{ Soil (B) } & \multirow[t]{6}{*}{62.5} & \multirow[t]{3}{*}{3} & 7 & 0.11 & $<0.05$ & $<0.05$ & 0.11 & $<0.05$ \\
\hline & & & 10 & 0.135 & $<0.05$ & $<0.05$ & 0.051 & $<0.05$ \\
\hline & & & 14 & 0.134 & $<0.05$ & $<0.05$ & 0.050 & $<0.05$ \\
\hline & & \multirow[t]{3}{*}{4} & 7 & 0.092 & $<0.05$ & $<0.05$ & 0.080 & $<0.05$ \\
\hline & & & 10 & 0.17 & $<0.05$ & $<0.05$ & 0.096 & $<0.05$ \\
\hline & & & 14 & 0.11 & $<0.05$ & $<0.05$ & 0.13 & $<0.05$ \\
\hline & \multirow[t]{6}{*}{93.75} & \multirow[t]{3}{*}{3} & 7 & $<0.05$ & $<0.05$ & $<0.05$ & 0.14 & $<0.05$ \\
\hline & & & 10 & $<0.05$ & $<0.05$ & $<0.05$ & 0.20 & $<0.05$ \\
\hline & & & 14 & 0.06 & $<0.05$ & $<0.05$ & 0.18 & $<0.05$ \\
\hline & & \multirow[t]{3}{*}{4} & 7 & 0.17 & $<0.05$ & $<0.05$ & 0.12 & $<0.05$ \\
\hline & & & 10 & 0.12 & $<0.05$ & $<0.05$ & 0.24 & $<0.05$ \\
\hline & & & 14 & 0.13 & $<0.05$ & $<0.05$ & 0.19 & $<0.05$ \\
\hline
\end{tabular}


Table 5 Dissipation of fluopicolide and cyazofamid in soil and grapes in supervised field trials (2017)

\begin{tabular}{|c|c|c|c|c|c|}
\hline \multirow[b]{3}{*}{ Sample } & \multirow[b]{3}{*}{ PHI (day) } & \multicolumn{4}{|c|}{ Residue $\left(\mathrm{mg} \mathrm{kg}^{-1}\right)$} \\
\hline & & \multicolumn{2}{|c|}{ Fluopicolide } & \multicolumn{2}{|c|}{ Cyazofamid } \\
\hline & & Hebei & Anhui & Hebei & Anhui \\
\hline \multirow[t]{8}{*}{ Grapes } & 0 & 0.25 & 1.06 & 0.22 & 0.74 \\
\hline & 1 & 0.19 & 0.53 & 0.13 & 0.36 \\
\hline & 3 & 0.27 & 0.78 & 0.21 & 0.53 \\
\hline & 5 & 0.12 & 0.64 & 0.09 & 0.43 \\
\hline & 7 & 0.10 & 0.19 & 0.07 & 0.12 \\
\hline & 14 & 0.12 & 0.52 & 0.08 & 0.32 \\
\hline & 21 & 0.14 & 0.39 & 0.09 & 0.22 \\
\hline & 30 & 0.09 & 0.11 & 0.05 & $<0.05$ \\
\hline \multirow[t]{8}{*}{ Soil } & 0 & 0.21 & 0.20 & 0.15 & 0.12 \\
\hline & 1 & 0.18 & 0.17 & 0.42 & 0.08 \\
\hline & 3 & 0.14 & 0.13 & 0.17 & $<0.05$ \\
\hline & 5 & 0.18 & 0.17 & $<0.05$ & $<0.05$ \\
\hline & 7 & 0.18 & 0.17 & 0.09 & $<0.05$ \\
\hline & 14 & 0.18 & 0.17 & $<0.05$ & $<0.05$ \\
\hline & 21 & 0.10 & 0.10 & $<0.05$ & $<0.05$ \\
\hline & 30 & 0.07 & 0.06 & $<0.05$ & $<0.05$ \\
\hline
\end{tabular}

shown in Table 5, Fig. 5 and 6 show the dissipation trends of fluopicolide and cyazofamid in grapes as well as soil.

The dissipation of fluopicolide gives the equations $C=$ $0.9889 \mathrm{e}^{-0.0605 t}$ (Anhui, grapes), $C=0.1959 \mathrm{e}^{-0.0351 t}$ (Anhui, soil), $C=0.1765 \mathrm{e}^{-0.0318 t}$ (Hebei, grapes), and $C=0.2128 \mathrm{e}^{-0.0327 t}$ (Hebei, soil) with correlation coefficients $(R)$ of $0.9666,0.9847$, 0.7325 , and 0.9430 and half-lives of 11.4, 19.7, 21.8, and 21.2 days, respectively. The dissipation of cyazofamid gives the equations $C=0.7134 \mathrm{e}^{-0.0799 t}$ (Anhui, grapes) and $C=$ $0.1285 \mathrm{e}^{-0.0344 t}$ (Hebei, grapes) with correlation coefficients $(R)$ of 0.9679 and 0.6903 , and half-lives of 8.7 and 20.1 days, respectively. Most of the residue data for cyazofamid in soil is lower than the LOQ values for this method, two points cannot precisely trace the dissipation line.

Supervised field trials of fluopicolide on tomatoes have been previously carried out. ${ }^{16}$ Sahoo et al. ${ }^{16}$ found residues of fluopicolide with values of 93.75 and $187.50 \mathrm{~g}$ a.i. ha ${ }^{-1}$. After 5 days, the residues were 0.07 and $0.15 \mathrm{mg} \mathrm{kg}^{-1}$ and fluopicolide was found to have dissipated below the LOD of $0.01 \mathrm{mg} \mathrm{kg}^{-1}$ in 7 and 10 days for single and double dosages. The half-lives were 2.58 and 2.31 days, respectively, far less than grapes in Suzhou and Longyao. However, they did not monitor the M-01 and M-02 residues.

As for cyazofamid, there have been reports on both tomatoes and soil. ${ }^{18}$ Cyazofamid was found to dissipate slowly in tomatoes within 5 days after application, and the half-life of cyazofamid dissipation in tomatoes in ZJ and $\mathrm{HN}$ were found to be 12.2 and 18.3 days, longer than that in Longyao but shorter than that in Suzhou. Their LOQ for CCIM was $0.01 \mathrm{mg} \mathrm{kg}^{-1}$ and most of their results were lower than the LOQ, which fits the research results for CCIM in this study.

The initial concentrations of cyazofamid in grapes were 0.74 and $0.22 \mathrm{mg} \mathrm{kg}^{-1}$ in Anhui and Hebei, and 0.12 and $0.15 \mathrm{mg}$ $\mathrm{kg}^{-1}$ in soil. As for fluopicolide, the initial concentrations in grapes were 1.06 and $0.25 \mathrm{mg} \mathrm{kg}^{-1}$ in Anhui and Hebei, and 0.2 and $0.21 \mathrm{mg} \mathrm{kg}^{-1}$ in soil. The difference in the concentrations between the grape samples from the two places may be a result of the grape planting density, weather conditions and method of application.

As for the differences in the half-life, both cyazofamid and fluopicolide were found to degrade more quickly in Anhui than in Hebei, in around half the half-life of that of the Hebei samples. The different environmental conditions should be taken into consideration, such as temperature, humidity, amount of sunlight, etc. ${ }^{31}$ The weather history was taken from an internet source and used to construct a plot, which is shown in Fig. 7. It can be seen that the temperatures in these two places are roughly the same, but that there is more probability of rainfall in Suzhou. It makes sense that high humidity speeds up the degradation of the pesticide.

High-community half-lives in the soil in these places are caused by the texture of the soil. It was found that the soil in these two places was clay. The soil in Suzhou was found to have a higher viscosity, which means that it can resist leaching and well retain the compounds. This may explain why Suzhou has more rainfall, but the soil there has a similar half-life to that in Longyao.

3.2.3. Health risk assessment. According to the GAPs (good agricultural practice) data of the European Union, Canada and the USA, a MRL for fluopicolide in grapes of $2 \mathrm{mg} \mathrm{kg}^{-1}$ was agreed upon in 2009. ${ }^{7}$ The MRL for cyazofamid in grapes is $1 \mathrm{mg}$ $\mathrm{kg}^{-1}{ }^{10}$ Although, even if there is low toxicity and low residues of fluopicolide and cyazofamid in grapes and soil, it does not mean that there is no risk to the human body. Intake risks of
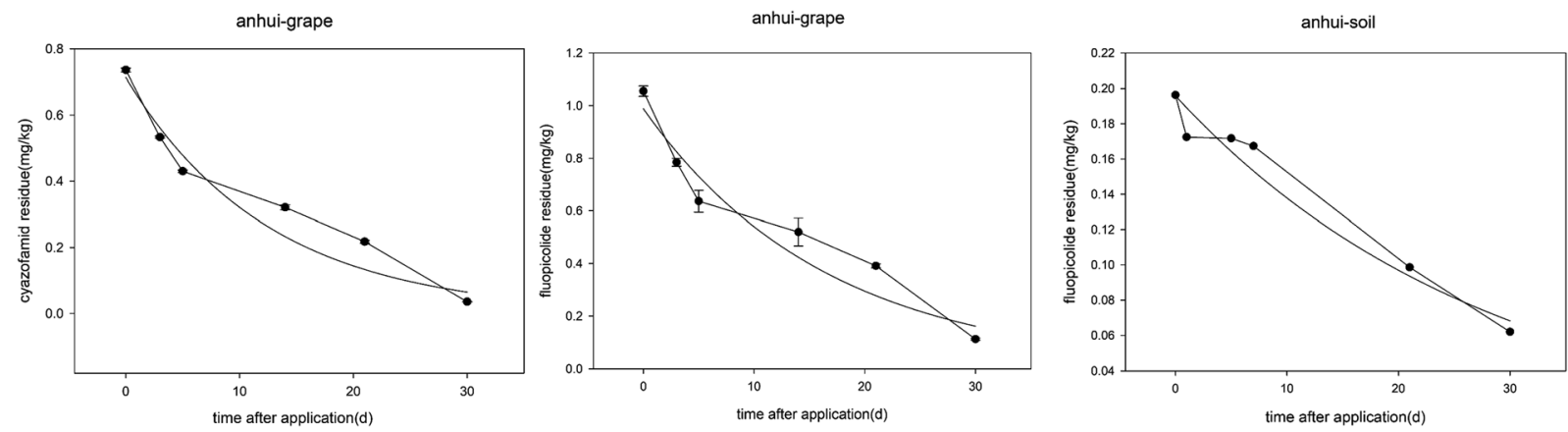

Fig. 5 Dissipation of fluopicolide and cyazofamid in grapes and soil in Anhui Suzhou. 

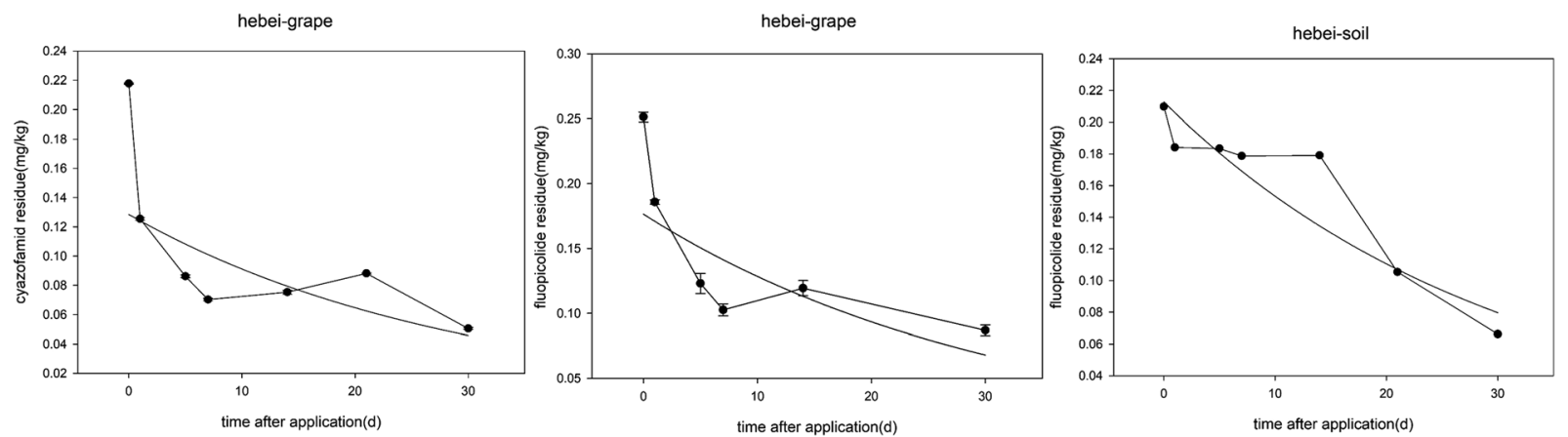

Fig. 6 Dissipation of fluopicolide and cyazofamid in grapes and soil in Hebei Longyao.

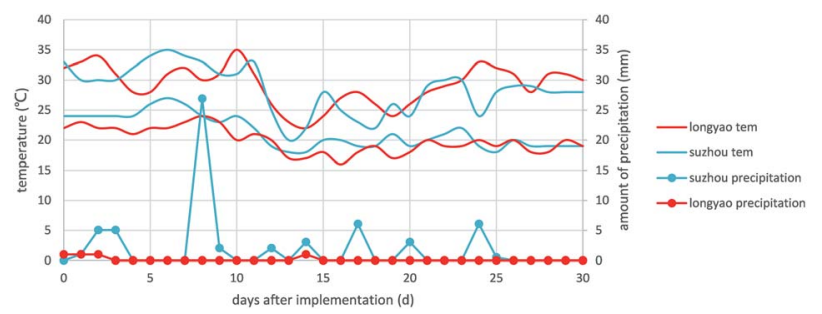

Fig. 7 Temperature and precipitation conditions in Anhui Suzhou and Hebei Longyao.

fluopicolide and cyazofamid in grapes were assessed in this study.

For long-term risk assessment of cyazofamid, the ADI value is $0.2 \mathrm{mg} \mathrm{kg}^{-1} \mathrm{bw}$, and the ARfD is thought to be unnecessary, according to JMPR. ${ }^{10}$ When the concentration of the metabolite is lower than the LOQ, the LOQ was used to calculate the STMR and HR, so the STMR of cyazofamid in grapes was found to be $0.20 \mathrm{mg} \mathrm{kg}{ }^{-1}$ from the data of the supervised experiments. As the daily grape intake is $0.046 \mathrm{~kg}$ per day, ${ }^{27}$ the HQ of cyazofamid was calculated as $0.077 \%$ using formulas (4) and (5). The HQ was below $100 \%$, indicating that there is little risk for the grape intake.

In terms of the risk assessment of fluopicolide, the ADI is $0.08 \mathrm{mg} \mathrm{kg}^{-1} \mathrm{bw}$, and the ARfD is $0.6 \mathrm{mg} \mathrm{kg}^{-1} \mathrm{bw}$ for women of childbearing age. The STMR and HR of fluopicolide in grapes were found to be 0.30 and $0.79 \mathrm{mg} \mathrm{kg}^{-1}$, respectively. The calculated HQ value of fluopicolide was $2.875 \%$, and the calculated aHI value of fluopicolide was $2.414 \%$ using formulas (6) and (7). Both the HQ and aHI values were below $100 \%$, indicating that there is little chronic and acute risk in consuming grapes.

\section{Conclusion}

A QuEChERS method using LC-MS/MS was developed and verified to estimate the residue levels of fluopicolide, cyazofamid and their metabolites in grape and soil samples. The dissipation and final residues in a grape field ecosystem were studied by means of this developed method. The half-lives of fluopicolide were found to be 11.4 (Anhui, grapes), 19.7 (Anhui, soil), 21.8 (Hebei, grapes), and 21.2 days (Hebei, soil), respectively. The dissipation of cyazofamid could be described using first-order equations and was found to have half-lives of 8.7 (Anhui, grape) and 20.1 days (Hebei, grape), respectively. The differences in the degradation of the pesticides in the samples in Anhui and Hebei were clarified, and it was illustrated that the degradation of both fluopicolide and cyazofamid in grapes in Anhui was quicker than in Hebei. The final grape residues were below the MRL established by the JMPR and China at PHIs of 7 , 10 and 14 days. Thus, a PHI of 10 days and a MRL of $2.0 \mathrm{mg} \mathrm{kg}^{-1}$ for fluopicolide and $1 \mathrm{mg} \mathrm{kg}^{-1}$ for cyazofamid are appropriate for ensuring food safety. A long-term and short-term risk assessment was also carried out. A HQ value of $0.077 \%$ was determined for cyazofamid and $2.875 \%$ for fluopicolide, and the aHI of fluopicolide was found to be $2.414 \%$, values which are obviously below $100 \%$ and imply that the use of cyazofamid and fluopicolide in grapes at the recommended dosage poses a low risk to human health.

\section{Conflicts of interest}

There are no conflicts to declare.

\section{Notes and references}

1 OIV, World VitiViniculture Situation OiV StatiStical report on World VitiViniculture, 2017, http:/www.oiv.int/public/ medias/5479/oiv-en-bilan-2017.pdf.

2 M. Brilli, E. Asquini, M. Moser, P. L. Bianchedi, M. Perazzolli and A. Si-Ammour, Sci. Rep., 2018, 8, 757.

3 V. Toquin, F. Barja, C. Sirven, S. Gamet, M. P. Latorse, J. L. Zundel, F. Schmitt and R. Beffa, A new mode of action for fluopicolide: Modification of the cellular localization of a spectrin-like protein, 2006.

4 T. Ohshima, T. Komyoji, S. Mitani, N. Matsuo and T. Nakajima, J. Pestic. Sci., 2004, 136-138.

5 K. L. Jackson, J. Yin, A. S. Csinos and P. Ji, Crop Prot., 2010, 29, 1421-1427.

6 M. P. Latorse, D. Holah and R. Bardsley, PflanzenschutzNachr. Bayer, 2006, 59, 185-200.

7 FAO, Food and Agriculture Organization of the United Nations, List of pesticides evaluated by JMPR and JMPS-P, 2009, http:/www.fao.org/fileadmin/templates/agphome/ 
documents/Pests_Pesticides/JMPR/Report09/

Fluopicolide.pdf.

8 Ministry of Agriculture and Rural Affairs of the People's Republic of China, China Pesticide Information Network, http://www.chinapesticide.org.cn/yxcftozw.jhtml.

9 National Health and Family Planning Commission of PRC, Ministry of Agriculture and Rural Affairs of the People's Republic of China and China Food and Drug Administration, 2016.

10 FAO, Food and Agriculture Organization of the United Nations, List of pesticides evaluated by JMPR and JMPS-P, 2015, http://www.fao.org/fileadmin/templates/agphome/ documents/Pests_Pesticides/JMPR/Report2015/ CYAZOFAMID.pdf.

11 F. Hou, P. Teng, F. Liu and W. Wang, J. Agric. Food Chem., 2017, 65, 4484-4492.

12 L. Jiang, H. Wang, H. Xu, K. Qiao, X. Xia and K. Wang, Pest Manage. Sci., 2015, 71, 1008-1014.

13 M. H. Kabir, A. M. Abd El-Aty, M. M. Rahman, S. W. Kim, H. S. Lee, H. S. Chung, J. A. Do, J. H. Jeong, B. J. Chang, M. I. Chang, H. C. Shin and J. H. Shim, Environ. Sci. Pollut. Res. Int., 2017, 24, 22241-22250.

14 K. Shi, W. Li, L. Yuan, L. Li and F. Liu, Environ. Monit. Assess., 2015, 187, 698.

15 H. Lee, E. Kim, J.-K. Moon, Y.-Z. Zhu, J.-A. Do, J.-H. Oh, K. Kwon, Y. D. Lee and J.-H. Kim, J. Korean Soc. Appl. Biol. Chem., 2012, 55, 241-247.

16 S. K. Sahoo, K. Mandal, R. Kumar and B. Singh, Food Anal. Methods, 2013, 7, 1032-1042.

17 H. Lee, E. Kim, J. H. Lee, J. H. Sung, H. Choi and J. H. Kim, Bull. Environ. Contam. Toxicol., 2014, 93, 586-590.

18 Z. Xu, C. Zhang, J. Yu, C. Zhang, M. Wu, H. He, Y. Zhu, F. Lou, Y. Wu, Y. Wang, L. Chen, H. Zhao, Q. Wang and L. Cai, Environ. Sci. Pollut. Res. Int., 2017, 24, 3483-3492.
19 S. Mohapatra, A. K. Ahuja, M. Deepa, G. K. Jagdish, N. Rashmi, S. Kumar and G. S. Prakash, Bull. Environ. Contam. Toxicol., 2011, 86, 238-241.

20 T. Reemtsma, L. Alder and U. Banasiak, J. Chromatogr. A, 2013, 1271, 95-104.

21 M. Anastassiades, S. J. Lehotay, D. Stajnbaher and F. J. Schenck, J. AOAC Int., 2003, 86, 412-431.

22 Ministry of Agriculture and Rural Affairs of the People's Republic of China, 2004.

23 H. Trufelli, P. Palma, G. Famiglini and A. Cappiello, Mass Spectrom. Rev., 2011, 30, 491-509.

24 X. Feng, L. Pan, C. Wang and H. Zhang, Environ. Sci. Pollut. Res. Int., 2018, 25, 877-886.

25 FAO, Submission and Evaluation of Pesticide Residues Data for Estimation of Maximum Residue Levels in Food and Feed (FAO Plant Production and Protection Paper 197) [M]: 2009, Food and Agriculture Organization of the United Nations (FAO), Rome, 2nd edn, 2009.

26 World Health Organization, International estimated shortterm intake (IESTI), http:/www.who.int/foodsafety/chem/ guidance_for_IESTI_calculation.pdf.

27 D. Wang and X. Hua, J. Food Saf. Food Qual., 2017, 8, 10181024.

28 Q. M. Lu, L. H. Chen, M. H. Lu, G. N. Chen and L. Zhang, J. Agric. Food Chem., 2010, 58, 2763-2770.

29 X. You, L. Liang and F. Liu, Food Chem., 2014, 143, 170-174.

30 European Commission, Guidance document on pesticide residue analytical methods, https:/ec.europa.eu/food/sites/ food/files/plant/docs/pesticides_ppp_app-proc_guide_res_postreg-cont-monitor.pdf.

31 P. Fantke and R. Juraske, Environ. Sci. Technol., 2013, 47, 3548-3562. 